D) Check for updates

Cite this as: $B M J 2020 ; 371: m 3844$ http://dx.doi.org/10.1136/bmi.m3844 Published: 06 October 2020

\section{Matt Morgan: Why Dylan Thomas was wrong-and right}

We have amended this article by Matt Morgan (BMJ 2020;370:m3722, doi:, published 29 September 2020) to correct the spelling of the Welsh word mam-gu (grandmother). 